Z. klin. Chem. u. klin. Biochem.

8. Jg., S. $156-161$, März 1970

\title{
Some Hints to Avoid Pitfalls in Quantitative Determination of Glutathione Peroxidase (EC 1.11.1.9)
}

\author{
By L. Flohé and INGEBorg Brand
}

From the Institut für Physiologiscbe Chemie und Biocbemie der Universität Tübingen (Director: Prof. Dr. Dr. G. Weitzel)

(Eingegangen am 25. November 1969)

Methods of quantitative determination of glutathione peroxidase were reinvestigated with respect to reliability and specificity. The determination of product (GSSG) by a coupled enzymatic oxidation of NADPH, as described by PAGLIA and VALENIINE, had to be modified as follows: 1 . The concentration of GSH was lowered to a maximum of $1 \mathrm{~mm}$ in the incubation mixture to avoid product inhibition of GSSG reductase. 2. The concentration of $\mathrm{H}_{2} \mathrm{O}_{2}$ was increased to guarantee a sufficient amount of substrate to survive the lag phase of the coupled enzymatic test. The pretreatment of the samples proposed by PAGLIA and VALENTrine (13) was found to be insufficient for obtaining exact data on GSH peroxidase activity as all hemoglobin derivatives tested, including cyanmethemoglobin, caused a significant unspecific oxidation of GSH by $\mathrm{H}_{2} \mathrm{O}_{2}$. The determination of GSH peroxidase activity described by SCFNẼIDER and FLOHÉ (3). as well as their procedure to purify the enzyme prior to measurement was found to be reliable and adequately reproducible. In view of the lower apparative requirements, however, the procedure of PAGLIA and VALENTINE offers a more suitable clinical screening test if the possible errors mentioned below are considered. The influence of the medium on GSH peroxidase activity was investigated. The definitions of the enzyme unit are discussed with respect to the kinetic behaviour of GSH peroxidase. Our unit of activity is defined as the amount of enzyme dissolved in $1 \mathrm{ml}$ which effects a difference of 1 in the logarithms of the GSH concentrations per minute.

Methoden zur quantitativen Bestimmung von Glutathionperoxydase wurden in Hinsicht auf Verläßlichkeit und Spezifität geprüft. Die Bestimmung des Produktes (GSSG) mit Hilfe des gekoppelten enzymatischen Testes nach PaGLIA und ValentrNe mußte wie folgt modifiziert werden: 1 . Die GSH-Konzentration wurde auf maximal $1 \mathrm{~mm}$ im Inkubationsansatz gesenkt, um die Produkthemmung der Glutathionreduktase zu umgehen. 2. Die Konzentration von $\mathrm{H}_{2} \mathrm{O}_{2}$ wurde erhöht, um sicherzustellen, daß nach Verstreichen der dem Test eigentümlichen Lagphase noch ein ausreichendes Substratangebot gegeben ist. Die von PAGLIA und VaLentrNe vorgeschlagene Vorbehandlung der Proben erwies sich als unzureichend, wenn die Aktivität der Glutathionperoxydase exakt ermittelt werden soll, da sämtliche untersuchten Hämoglobinderivate einschließlich Cyanmethämoglobin eine signifikante unspezifische Glutathionoxydation durch $\mathrm{H}_{2} \mathrm{O}_{2}$ bewirken. Die von SCHNEIDER und FLOHÉ beschriebene Bestimmung der GSH-Peroxydase-Aktivität wie auch deren Vorschrift zur Abtrennung des Enzyms vor der Bestimmung erwies sich als zuverlässig und ausreichend reproduzierbar. Wegen des geringen apparativen Aufwands jedoch scheint die Methode von Paglia und VALENTINE unter Beachtung der genannten Fehlermöglichkeiten als klinischer Screening-Test geeigneter. Ferner wurde der Einfluß des Inkubationsmediums auf die Glutathionperoxydaseaktivität untersucht. Die Definitionen der Enzymeinheit werden diskutiert in Hinblick auf die kinetischen Eigenschaften der Glutathionperoxydase. Die von uns vorgeschlagene Enzymaktivität ist definiert als diejenige Enzymmenge (gelöst in $1 \mathrm{ml}$ ), die in der Minute eine Differenz der dekadischen Logarithmen der GSH-Konzentration von 1 bewirkt.

Due to its relation to HeInz body anemia and methemoglobinaemia (1, 2, 3, 12, 13), glutathione peroxidase (glutathione: $\mathrm{H}_{2} \mathrm{O}_{2}$ oxidoreductase EC 1.11.1.9) is of great interest in pediatric and internal medical research. Furthermore, the enzyme appears to play an important role in protecting biological membranes against oxidative damage not only in blood cells but in the whole organism. This is also indicated by its ubiquitous distribution $(4,5,6,7)$ and its ability to reduce hydroperoxides of unsaturated fatty acids $(6,8,9)$.

Nevertheless, there seems to be some confusion concerning the reliability and specificity of test methods for this enzyme. In this respect, the following should be considered: 1 . The reaction catalyzed by the enzyme (reaction (1), see below) proceeds spontaneously to an appreciable extent, at least in alkaline solutions. 2. Both substrates of the enzyme are able to react with a large number of compounds present in biological fluids so that the question of test specificity must be handled with special care. 3. The influence of the medium on GSH peroxidase activity has not been thoroughly investigated.
4. The kinetics of the enzyme are somewhat unusual in that substrate saturation (GSH) is not reached $(1,3$, $6,8)$. We may therefore briefly recall the methods employed so far to master these difficulties.

In 1957 MrLLs (10) reported the possibility of measuring GSH peroxidase activity by following its protective function against oxidation of hemoglobin. Though this procedure marks the beginning of work on GSH peroxidase it is only of historical interest today. Subsequently, the disappearance of GSH was determined by a series of further methods: 1 . The reaction of GSH with $p$ chloromercuribenzoate was used by Mirls (11). This method suffers from its poor sensitivity; in addition, some colored substances present even in the supernatants after $\mathrm{HClO}_{4}$ precipitation interfere with optical measurements at $255 \mathrm{~nm}$. 2. An amperometric determination of GSH was employed by CHRISTOPHERSEN (8). 3. A polarographic determination of GSH carried out in acid solution to avoid a further nonenzymatic reaction of $\mathrm{GSH}$ and $\mathrm{H}_{2} \mathrm{O}_{2}$ during measurement was proposed by Schneider and Flohé (3). 4. Cohen and 


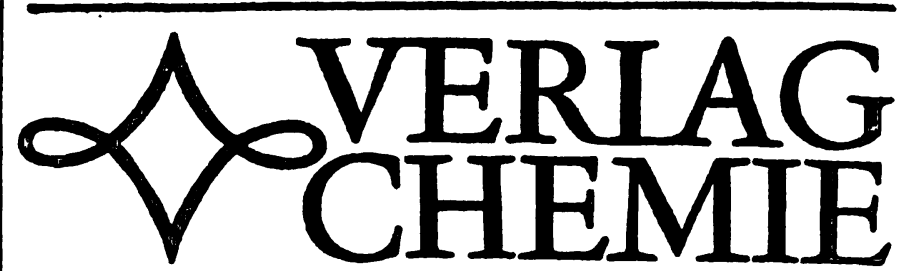

Soeben erscheint:

\section{Manfred Frank/Werner Stolz \\ Festkörperdosimetrie ionisierender Strahlung}

Bereits seit den Anfängen der Anwendung ionisierender Strahlung in der therapeutischen Praxis besteht das $\mathrm{Be}$ dürfnis nach physikalisch exakt definierten und experimentell meßbaren Dosisgrößen. Durch die Erschließung der Kernenergie ist dic Notwendigkeit entstanden, auch bei der Anwendung ionisierender Strahlung auf zahlreichen anderen Gebieten Dosismessungen durchzuführen.

In den letzten zehn Jahren erfolgten grundlegende Wandlungen und Fortschritte auf dem Gebiet der Dosimetrie ionisierender Strahlung. Die Entwicklung der Dosimetrie in diesem Zeitraum ist durch die Einführung neuer Meßverfahren und eine Neufassung der Definitionen der zu verwendenden Strahlungsgrößen und Einheiten gekennzeichnet. Die vorliegende Monographic beschäftigt sich mit einem Teilgebiet der Dosimetrie, der Dosimetrie mit anorganischen und organischen Festkörpern. Diese Disziplin hat sich stürmisch entwickelt und auch gegenwärtig wird noch intensive Forschungsarbeit geleistet. Die Hauptkapitel beschreiben die Theorie der Dosimetrie ionisierender Strahlung, die integrierende Festkörperdosimetrie, die Szintillationsdosimetrie und die Dosimetrie mit Halbleitern.

Methoden der Festkörperdosimetrie finden gegenwärtig in alle Gebiete der praktischen Dosimetrie, die Personendosimetrie, die klinische Dosimetrie, die strahlenbiologische Dosimetrie, die strahlentechnische Dosimetrie und die Reaktordosimetrie, Eingang. Die Autoren beschreiben ausführlich alle heute wichtigen Verfahren und geben Anregungen für die künftige Entwicklung und Forschung auf diesem aktuellen Gebiet. Besonderer Wert wird auf eine präzise Behandlung der physikalischen Grundlagen der verschiedenen Methoden der Festkörperdosimetrie gelegt. Dabei wird versucht, die vielfältigen Anwendungsmöglichkeiten der Festkörperdosimetrie hervortreten $\mathrm{zu}$ lassen. Über 500 geeignet ausgewählte Literaturzitate machen es dem Leser leicht, sich schnell über spezielle Einzelfragen weiter zu informieren.

1970. 283 Seiten mit 97 Abb. und 28 Tab. Leinen DM 48.-. IVir übersenden Ihnen gern unseren Sonderprospekt.

VERLAG CHEMIE - GMBH WEINHEIM/BERGSTR.

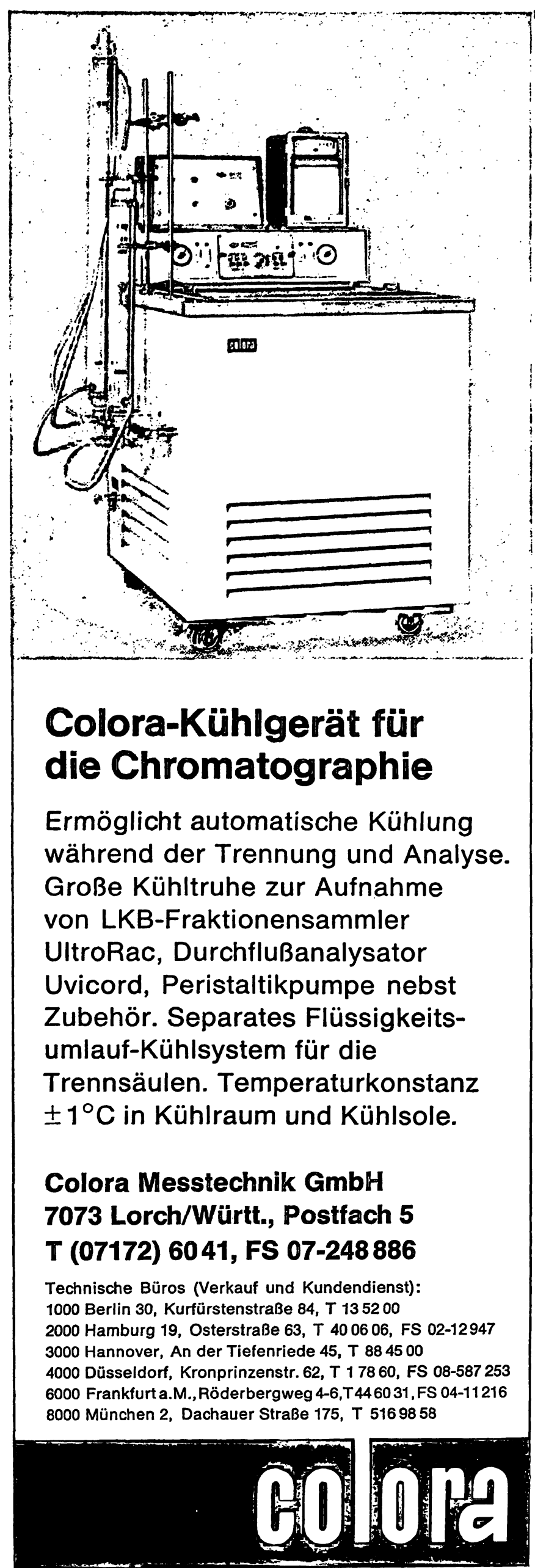




\title{
BULLETIN \\ DE LA \\ SOCIÉTÉ DE CHIMIE BIOLOGIQUE
}

\author{
(„Berichte der Gesellschaft für biologische Chemie“) \\ Unter Mitwirkung des \\ „CENTRE NATIONAL DE LA RECHERCHE SCIENTIFIQUE“ \\ (National-Centrum für wissenschaftliche Forschung) veröffentlicht
}

\author{
R. PERLES \\ Hilfs-Generalsekretär \\ J. E. COURTOIS \\ Generalsekretär \\ Y. RAOUL \\ Hauptredakteur
}

Sekretariat und Redaktion

4, avenue de l'Observatoire, Paris (6)

Herausgeber:

Masson et $\mathrm{C}_{\mathrm{IE}}, 120$, Boulevard Saint-Germain, Paris (6 $6^{\mathrm{e}}$ )

Der „Bulletin de la Société de Chimie Brologrqụe“ veröffentlicht jährlich 11 Hefte; diese enthalten die Arbeiten der französischen Biochemiker, welche der "SocrétÉ DE CHIMrE BrologrQue“ (Gesellschäft für biologische Chemie) angehören.

Abonnementspreis 1969:

Frankreich und „Franc-Zone“ . . . 150 francs

Belgien . . . . . . . . . 1684 belges

Andere Länder . . . . . . . 165 francs

\section{Un:allohirurgische Operationen}

\author{
Indikation Technik Fehler
}

\section{von Erich Jonasch}

2., erweiterte und verbesserte Auflage mit einem Geleitwort von Lorenz Böhler Quart. XII, 143 Seiten. Mit 121 Abbildungen in 315 Einzeldarstellungēn. 1970. Plastikeinband DM 48, -

Die zweite, erweiterte Auflage bringt die Darstellung neuer, bewährter Operationșverfahren bei Verlètzungen des Schädels, der Wirbelsäule und der Körperhöhlen.

Die Technik der einzelnen Operationen wird ausführlich beschrieben und durch zahlreiche schematische Zeichnungen und Röntgenbilder erläutert, so daß für den Operateur eine schnelle und ausführliche Orientierung möglich ist.

Bei jeder Operation ist auch die Indikation zur Operation angeführt.

Neben den typischen Eingriffen werden bei jedem Abschnitt häufig beobachtełe Fehler, seien sie technischer oder indikationsmäßiger Art, besprochen und ihre Ursachen aufgezeigt.

Das kurz und prägnant gefaßte Buch bringt somit einen höchst akłuellen und interessanten Beitrag zur Frage der operativen Knochenbruchbehandlung und eine Übersicht über die notwendigen typischen unfallchirurgischen Operationen, die im Unfallkrankenhaus Wien XX bei Professor Böhler durchgeführt werden.

Die Einstellung der Böhler-Schule in der Knochenbruchbehandlung ist bekanntlich konservativ, und es wird nur operiert, wenn eine konservative Behandlung allein nicht zum Ziel führt.

Wie großeReihen von Nachuntersuchungen zeigten, haben sich diese unfallchirurgischen Operationen bewährt. 
Hochstein (12) and Gross, Bracci, Rudolph, SchroeDER and KOCHEN (2) performed the reaction of GSH with nitroprusside after having removed $\mathrm{H}_{2} \mathrm{O}_{2}$ from the reaction mixture. This method, however, will never reach the reproducibility of the electrometric determinations cited above due to the instability of the dye. Finally, PAGLIA and VALENTINe (13) described an elegant method by which the formation of product (GSSG) is determined continously by a coupled enzymatic oxidation of NADPH via glutathione reductase.

Only few approaches have been made to render the tests specific in unpurified biological material. Catalase usually is inhibited by $\mathrm{NaN}_{3}$. A complete inhibition of catalatic activity by $\mathrm{N}_{3}^{-}$, however, does not prevent catalase from reacting with GSH (14). MrLls tried to reduce the unspecific reactions by precipitating the bulk of proteins by organic solvents (4). This procedure, however, does not produce reliable results if samples of different tissues are to be investigated. In 1967 we proposed the pretreatment of samples by chromatography on Sephadex G 150 before determining GSH peroxidase activity in order to eliminate the most interfering proteins, hemoglobin and catalase (3). Although we knew from our preparative work on GSH peroxidase that this step would not result in an appreciable loss of active material, no exact information on recovery and reproducibility was available. To avoid oxidation of GSH by hemoglobin, PAgLIa and Valentine (13) suggested that hemoglobin be converted into cyan methemoglobin by $\mathrm{K}_{3}\left[\mathrm{Fe}(\mathrm{CN})_{6}\right]$ and $\mathrm{KCN}$ prior to investigating the samples by the method cited above. However, there is no evidence that the "GSH peroxidatic effect" of hemoglobin is abolished by this procedure.

The purpose of our work is to reinvestigate the possibility of using the reaction of glutathione reductase as an indicator of GSH peroxidase activity, to study the influence of the medium on GSH peroxidase activity, to obtain further information on interfering reactions and to demonstrate the reproducibility of the procedure of ref. (3).

\section{Materials and Methods}

NADPH, NADP, GSSG and glutathione reductase from yeast were purchased from Boehringer (Mannheim, Germany). Liquemin was a product of Hoffmann La Roche (Grenzach, Germany). Sephadex G 50 coarse, G 150 and DEAE Sephadex A 50 (Pharmacia, Uppsala, Sweden) were used for column chromatography. All other reagents were products "pro analysi" of Merck A. G. (Darmstadt, Germany).

Highly purified GSH peroxidase was prepared from bovine erythrocytes according to the method of SCHNEIDER and FLOHÉ (3). The final product had a specific activity of about $70 \mathrm{U} / \mathrm{mg}$ protein $\left(\mathrm{U}: \Delta \mathrm{lg} \mathrm{C}_{\mathrm{GSH}} / \mathrm{min}=1\right.$ ).

Some crystallized hemoglobin derivatives $\left(\mathrm{HbO}_{2}, \mathrm{HbCO}\right.$ and cyanmethemoglobin) were prepared from bovine erythrocytes according to ref. (15) after removal of catalase and GSH peroxidase by DEAE-Sephadex chromatography (3). The absence of GSH peroxidase was confirmed by chromatography on Sephadex G 150; no GSH peroxidase activity could be detected in the eluate at the position specific for this enzyme. The hemoglobin specimens were identified by their spectral characteristics (16). The molar ratio of $\mathrm{CN}^{-}$to heme during crystallization of cyanmethemoglobin was about 100:1.

Determinations of protein and bemoglobin were carried out according to ref. (17) and (18), respectively.

Glutatbione reductase activity' was mcasured according to HoRN (19). O. D. readings were taken at $366 \mathrm{~nm}$ in an Eppendorf photometer. Reversibility of glutathione reductase under the conditions of procedure II (see below) was tested by replacing GSSG by GSH at increasing concentrations. GSH solutions of concentrations higher than $1 \mathrm{~mm}$ were neutralized immediately before use. Glutathione reductase activity was determined at varying concentrations of GSH. For this purpose the test samples were composed as follows: $1 \mathrm{ml}$ potassium phosphate buffer, $0.5 \mathrm{M}$, $\mathrm{pH} 7.0 ; 1 \mathrm{~mm}$ EDTA; $0.1 \mathrm{~m} / 14.4 \mathrm{~mm} \mathrm{NADPH}$ in $0.1 \% \mathrm{NaHCO}_{3}$; $0.2 \mathrm{ml} 7.5 \mathrm{~mm}$ GSSG neutralized by $1 \mathrm{~N} \mathrm{KOH} ; 0.5 \mathrm{ml} \mathrm{H}_{2} \mathrm{O}$ or GSH; $\mathrm{H}_{2} \mathrm{O}$ to give a final volume of $3 \mathrm{~m} /$, and $0.1 \mathrm{~m} /$ glutathione reductase $\left(2.25 \mathrm{I}\right.$. U./ml). The incubation temperature was $25^{\circ}$.

GSH peroxidase activity was mcasured by two methods:

1. The polarographic test of SCHNEIDER and FLOHÉ (3) (designated procedure I).

2. A modification of the method of Paglia and VALENTine (13) (designated procedure II).

Procedure I:

$1 \mathrm{~m} /$ of buffered enzyme solution $(0.1 \mathrm{M}$ potassium phosphate, $\mathrm{pH} 7.0 ; 1 \mathrm{~mm}$ EDTA, if not otherwise stated) was equilibrated for 10 minutes in a water bath at $37^{\circ}$ or $25^{\circ}$. 10 seconds after the addition of $0.5 \mathrm{ml} 5 \mathrm{mM} \mathrm{H}_{2} \mathrm{O}_{2}$ the reaction was started by the addition of $0.5 \mathrm{ml} 4 \mathrm{~mm}$ GSH solution. At various times thereafter the reaction was stopped by injection of $2 \mathrm{ml}$ of $1.18 \mathrm{M}$ perchloric acid. The initial substrate concentration was determined by adding the perchloric acid prior to the GSH solution. The spontaneous reaction rate was followed in analogous samples without enzyme. The polarographic determination of GSH was performed exactly as described in ref. (3) using the polarograph PO 4 of Radiometer Copenhagen.

\section{Procedure II}

The following solutions were pipetted into a $3 \mathrm{ml}$ silica cuvette: $0.1 \mathrm{~m} l \mathrm{GSH}$ peroxidase solution; $0.2 \mathrm{~m} /$ glutathione reductase solution $\left(0.02 \mathrm{mg} / \mathrm{m} / 2.8 \mathrm{M}\left(\mathrm{NH}_{4}\right)_{2} \mathrm{SO}_{4}=1.6 \mathrm{I}\right.$. U. $\left./ \mathrm{ml}\right) ; 0.2 \mathrm{ml} 3.6 \mathrm{~mm}$ NADPH, $0.5 \mathrm{ml} 4 \mathrm{~mm}$ GSH; $1.0 \mathrm{ml} 0.1 \mathrm{M}$ potassium phosphate buffer $\mathrm{pH} 7.0,1 \mathrm{~mm}$ EDTA. The samples were kept at $25^{\circ}$ by a cuvette thermostat. The reaction was initiated by addition of $0.5 \mathrm{ml}$ $5 \mathrm{~mm} \mathrm{H}_{2} \mathrm{O}_{2}$. The optical density was read at $366 \mathrm{~nm}$ in an Eppendorf photometer, beginning 1 minute after mixing the sample. The oxidation of GSH was calculated using an extinction coefficient of $3.3\left(\mathrm{~cm}^{2} / \mu \mathrm{Mol}\right)$ for NADPH (19).

GSH peroxidase activity of the hemoglobin samples was examined by procedure I and II, replacing the enzyme by an hemoglobin solution.

\section{Procedure IIa:}

To illustrate the limitations of procedure II at increasing concentrations of GSH the test was modified as follows:

$1.0 \mathrm{ml} 0.5 \mathrm{M}$ potassium phosphate buffer $\mathrm{pH} 7,1 \mathrm{~mm}$ EDTA, $0.1 \mathrm{~m} / 14.4 \mathrm{~mm} \mathrm{NADPH}, 0.5 \mathrm{ml} \mathrm{GSH}$ (neutralized by $1 \mathrm{~N} \mathrm{KOH}$ at concentrations exceeding $1 \mathrm{~mm}$ ), $0.1 \mathrm{ml}$ glutathione reductase solution ( $6 \mathrm{I} . \mathrm{U} . / \mathrm{m} /), 0.05 \mathrm{~m} /$ glutathione peroxidase solution or $\mathrm{H}_{2} \mathrm{O}$, respectively, and $\mathrm{H}_{2} \mathrm{O}$ to give a final volume of $3 \mathrm{ml}$ were equilibrated at $25^{\circ}$. The reaction was initiated by addition of $0.5 \mathrm{~m} / 5 \mathrm{mM} \mathrm{H}_{2} \mathrm{O}_{2}$.

GSH peroxidase activity was determined according to procedure I at $37^{\circ}$ in a pariely of buffer solutions. To elucidate the influence of anions on the enzyme activity, a known amount of acid was adjusted to $\mathrm{pH} 7.6$ by the tris base and filled up with distilled water to give a specified molarity of the anion. 
Reproducibility of column cbromatograplby': A given amount of GSH pcroxidase was applied to a column (dimensions: length: $150 \mathrm{~cm}$, diameter: $1.5 \mathrm{~cm}$ ) filled with Sephadex G 150, equilibrated with $5 \mathrm{~mm}$ phosphate buffer, $\mathrm{pH}$ 7.2. The chromatography was carried out at a flow rate of $12-15$ drops per minute. The activity of the eluate was determined by the polarographic test. The whole procedure was repeated six times.

\section{Results and Discussion}

\section{Test methods}

As published in ref. (3), the polarograpbic determination of GSH is highly reproducible. The standard deviation is about $2 \%$ at concentrations of 1 to $0.05 \mathrm{mM}$ in the final test sample - equivalent to 2 to $0.1 \mathrm{~mm}$ in the incubation medium. However, in the next lower decimale the standard deviation rises to about $5 \%$ and more, and no reliable results can be obtained with our equipment at concentrations below $5 \mu \mathrm{M}$. Considering the errors conditioned by starting and stopping the enzymatic reaction, the overall standard deviation of procedure I amounts to ca. $3 \%$ under normal conditions. The second test system may be summarized by the following equations :

$$
\begin{array}{lll}
2 \mathrm{GSH}+\mathrm{H}_{2} \mathrm{O}_{2} \stackrel{\text { GSH peroxidase }}{\longrightarrow} & 2 \mathrm{H}_{2} \mathrm{O}+\mathrm{GSSG} \\
\mathrm{GSSG}+\mathrm{NADPH}+\mathrm{H}^{+} \stackrel{\text { GSSG reductase }}{\longrightarrow} \mathrm{NADP}+ \\
& +2 \mathrm{GSH}
\end{array}
$$

Procedure II differs from the test system described by Paglia and Valentine (13) only in the concentrations of the substrates. This modification is justified by the following reasons:

1. The standard concentration of $\mathrm{H}_{2} \mathrm{O}_{2}(73.3 \mu \mathrm{M})$ used by Paglia and VAlentine (13) seems to be too low. A constant decrease of optical density is not observed before 1 minute after mixing the sample. However, all $\mathrm{H}_{2} \mathrm{O}_{2}$ may have reacted at that time if the activity of the GSH peroxidase exceeds $0.1 \mathrm{U}$ per $\mathrm{ml}$ of test sample. We may offer a further argument against the concentration of $\mathrm{H}_{2} \mathrm{O}_{2}$ proposed by PAGLIA and VALENTINE: The concentration only slightly exceeds the $\mathrm{K}_{\mathrm{m}}\left(\mathrm{H}_{2} \mathrm{O}_{2}\right)$ of $\mathrm{GSH}$ peroxidase $(25 \mu \mathrm{M})$ calculated by these authors (13). Under these conditions pseudo second order kinetics must be expected so that the enzyme activity may not be expressed in either international or logarithmic units. (It should be mentioned that this $K_{m}$ value is not in agreement with the zero order reaction rate with respect to $\mathrm{H}_{2} \mathrm{O}_{2}$ observed by several authors up to a concentration of $10 \mu_{\mathrm{M}}(3,6,8,20)$. Recently we were able to determine an apparent $\mathrm{K}_{\mathrm{m}}\left(\mathrm{H}_{2} \mathrm{O}_{2}\right)$ value of about $1 \mu \mathrm{M}$ (21). These discrepancies, however, may partially be explained by differences in the donor concentrations of the relevant experiments $(21,22)$.

2. The concentration of GSH is reduced from $5 \mathrm{~mm}$ to $1 \mathrm{~mm}$ since a strong product inhibition of glutathione reductase may affect the overall reaction rate at higher concentrations (Fig. 1). This product inhibition has already been described by Scotr and coworkers (23) for glutathione reductase of human erythrocytes. Since the equilibrium constant of reaction (2) had been determined to be $98 \times 10^{7}(23)$, the reversibility of GSSG reductase could be neglected under the conditions of the test system. We could confirm that the inhibition of enzymatic GSSG reduction by GSH is not caused by a reverse reaction. The product inhibition of glutathione reductase and the fact that GSH peroxidase, in contrast

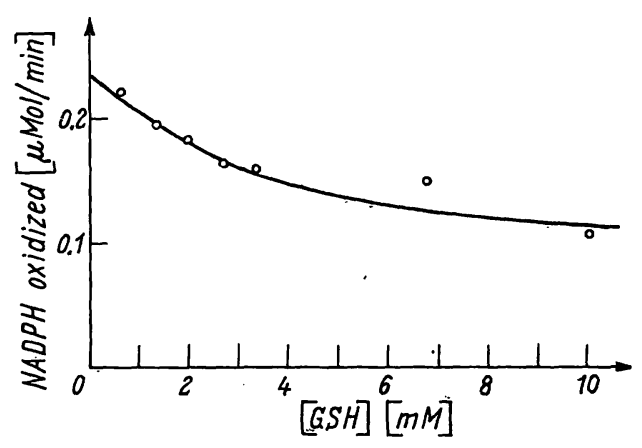

Fig. 1

Product inhibition of glutathione reductase. The graph shows the dependency of activity on the molarity of GSH in the incubation reaction rate is given in $\mu$ moles NADPH oxidized per sample per minute

to GSH reductase, follows first order kinetics at all donor concentrations complicate the estimation of GSH peroxidase activity under extreme conditions: In order to obtain the actual reaction rate of GSH peroxidase at $10 \mathrm{~mm}$ GSH by the coupled enzymatic test the experiment must be performed at a concentration of GSH reductase which is at least twenty-fold higher than that sufficient at $1 \mathrm{mM} \mathrm{GSH}$. Because of the high costs of GSH reductase and due to the inevitable involvement of foreign protein and various ions which may influence the GSH peroxidase reaction itself (see below), we consider this alternative inadvisable. In order to illustrate the limitations of the coupled enzymatic test, Fig. 2 presents a set of experiments concerning the GSH dependency of the GSH peroxidase reaction. The results

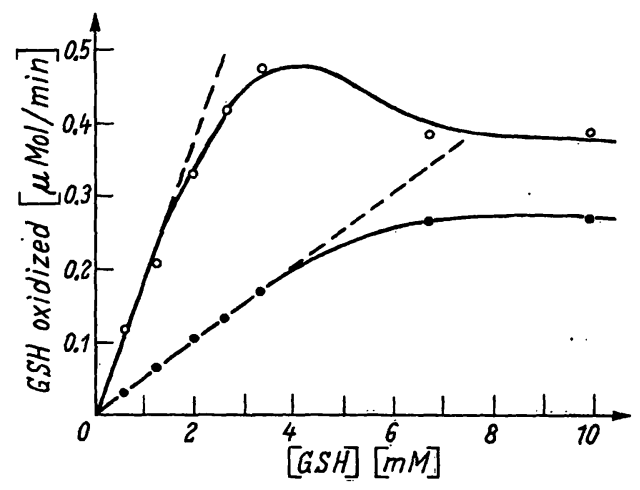

Fig. 2 Limitations of procedure 11 : glutathione peroxidase is determined "methods") at varying concentrations of GSH. The reaction rate is given in $\mu$ moles GSH oxidized per sample per minute.

$\because-$ enzymatic oxidation of GSH, as indicated by procedure II a -.-. spontaneous oxidation of $\mathrm{GSH}$, as indicated by the test.

For comparison the dotted lines indicate the respective slopes obtained by the polarographic test $(21,26)$ 
were obtained at GSH reductase concentrations which were sufficient under our standard conditions. As can be seen from the graph, substrate saturation and final substrate inhibition of GSH peroxidase is indicated at concentrations higher than $1 \mathrm{mM}$. This is actually caused by product inhibition of GSSG reductase. Recently Pinto and Bartley (24) avoided these difficulties by stopping reaction (1) after a given time and determining GSSG enzymatically according to equation (2).

A linear proportionality between reaction rate of GSH peroxidase and GSH concentration has been found by all methods estimating immediately the substrate $\mathrm{GSH}$ $(3,6,8,21,26)$. On the other hand, PAgLia and VALENTINE (13) and recently HochsteIN and UTLEY (20), using the coupled enzymatic test system, described deviations from the first order reaction type at high concentrations of GSH. Our findings indicating that the applicability of procedure II is restricted to GSH concentrations below $1 \mathrm{~mm}$ may explain these discrepancies. In his recent work on glutathione peroxidase of bovine lens Holmberg (28) obtained results on the kinetics of the enzyme by the coupled enzymatic test wich are consistent with ours $(3,21)$. His investigations, however, were not extended to the extreme conditions under which the kinetic experiments of PAGLIA and VALENTINE were performed. In agreement with the present paper HolmBERG expresses doubts concerning the applicability of the coupled enzymatic test at high concentration of GSH and at alkaline $\mathrm{pH}$.

\section{Influence of the medium}

Figure 3 shows that the reaction rate of GSH peroxidase strongly depends on the buffers used. The apparent activity varies extremely in different buffer systems.

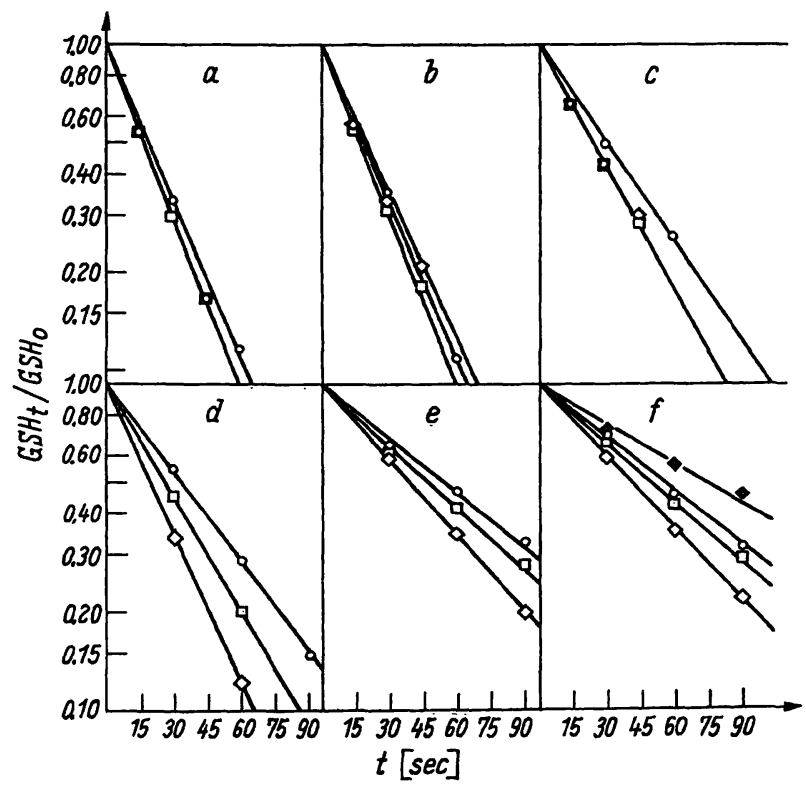

Fig. 3

Apparent activity of GSH peroxidase in a variety of buffers at $\mathrm{pH}$ 7.6. Molarity of the anions:

$\diamond \longrightarrow 0.05 \mathrm{M} ; \square \longrightarrow \square-\square 0.1 \mathrm{M} ; \circlearrowleft \longrightarrow 0.2 \mathrm{M} ; \multimap-01.0 \mathrm{M}$. A: tris acetate; $\quad$ B: tris formate; $\quad$ C: tris perchlorate $\begin{array}{lll}\text { A: tris acetate; } & \text { B: tris formate; } & \text { C: tris perchlor } \\ \text { D: tris phosphate; } & \text { E: tris maleate; } & \text { F: tris sulfate }\end{array}$
Besides, there is a strong dependency on ionic strength, at least if the medium contains multivalent anions. No significant difference in activity could be found in buffers containing different cations $\left(\mathrm{Na}^{+}, \mathrm{K}+\right.$, tris). We therefore conclude that the binding of anions to the enzyme is the molecular basis for the varying reactivity of the enzyme in different buffer solutions. This can be confirmed by the observation that the IP of GSH peroxidase depends on salt concentration (tris maleate system) in an analogous sense (25). The strong influence of the medium on GSH peroxidase activity must be kept in mind if results reported in the literature are to be compared.

\section{Specificity of test methods}

As already mentioned, the reaction of GSH peroxidase can be simulated by a variety of compounds. Traces of heavy metals for instance will catalyze the oxidation of $\mathrm{GSH}$ by $\mathrm{H}_{2} \mathrm{O}_{2}$. In addition, a large number of proteins react with GSH in the presence of $\mathrm{H}_{2} \mathrm{O}_{2}(3,13,14,27)$. Because of the first order kinetics of the GSH peroxidase reaction with regard to $\mathrm{GSH}$, these unspecific reactions will in any way interfere with the determination of activity by eliminating some GSH (through oxidation to GSSG or higher states of oxidation, absorption or binding to proteins etc.).

The procedure of Paglia and Valentine (13) promised rapid information on GSH peroxidase activity, at least in erythrocytes. A reinvestigation (Fig. 4, 5), however,

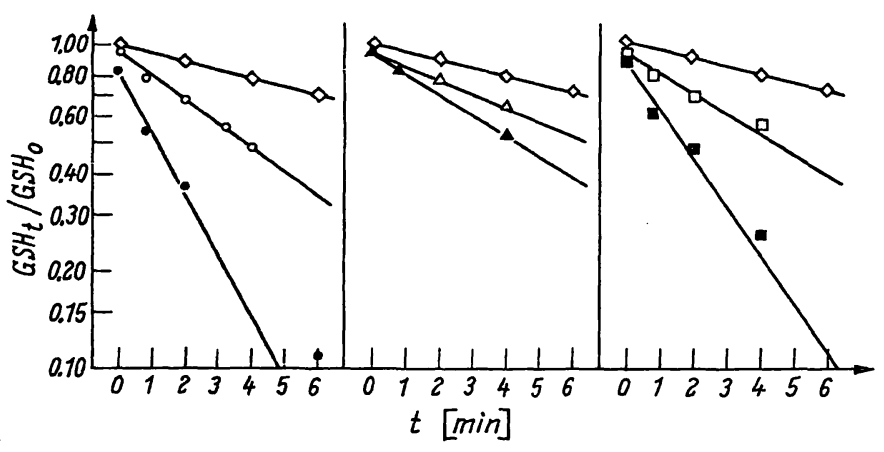

Fig. 4

Oxidation of $\mathrm{GSH}$ by $\mathrm{H}_{2} \mathrm{O}_{2}$ in the presence of several hemoglobin derivatives. The initial $\mathrm{GSH}$ concentration was identical throughout all experiments $(1 \mathrm{mM})$. The starting points of the curves below 1.0 indicate loss of recovery at zero time (see text). The GSH values were obtained by procedure I (see under "methods")

$\Delta-0-\Delta$ spontaneous reaction

$\triangle-\triangle-0.95 \mathrm{mg}$ cyanmethb

an $2.10 \mathrm{mg} \mathrm{HbO}$ 口-口- $0.70 \mathrm{mg} \mathrm{HbO}$.

The concentration of the hemoglobins is given in $\mathrm{mg}$ per sample $(2 \mathrm{ml})$

revealed that all hemoglobin derivatives examined, which are actually free of GSH peroxidase, catalyze the oxidation of $\mathrm{GSH}$ by $\mathrm{H}_{2} \mathrm{O}_{2}$. As can be seen from Figure 4, the disappearance of GSH is not conditioned by a single type of reaction. A significant loss of recovery of GSH at zero time, which is proportional to the concentration of the hemoglobins, is observed. Besides, we see a further catalytic oxidation of GSH which follows approximately 
first order kinetics (Fig. 3). The catalytic degradation of $\mathrm{GSH}$ rises with decreasing $\mathrm{pH}$ (in contrast to the GSH peroxidase reaction) and depends on the concentration of all reactants present although in a somewhat complicated manner. Thus, it remains uncertain to what extent this catalytic function is an intrinsic property of the proteins themselves and of degradation products formed during the experiments.

Whereas the data of Figure 4 show only the disappearance of GSH, the data of Figure 5, which were obtained

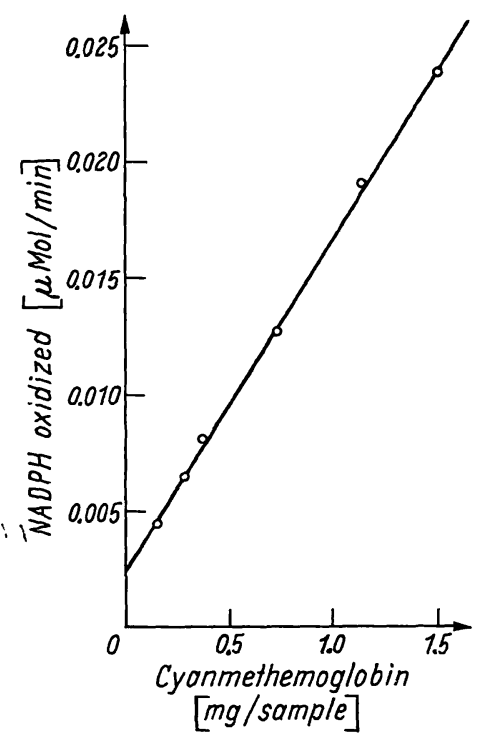

Fig. 5

GSSG obtained per minute by oxidation of $\mathrm{GSH}$ by $\mathrm{H}_{2} \mathrm{O}_{2}$ in the presence of cyanmethemoglobin. The formation of GSSG is followed by procedure II (for details see under "methods"). The amounts of cyanmethemoglobin are given in $\mathrm{mg}$ per sample $(2.5 \mathrm{ml})$

by procedure II, clearly indicate that GSH is oxidized at least in part to GSSG by cyanmethemoglobin. Thus, the statement of PAGLia and VALENTine (13) that the glutathione peroxidatic effect of hemoglobin is completely abolished by converting hemoglobin to cyanmethemoglobin cannot be reproduced by either method employed although the interfering catalytic function of hemoglobin is lowered to a degree which may be tolerable for a screening method.

For this reason we looked for a possibility of purifying peroxidase to a sufficient degree without loss of activity. As already mentioned in ref. (3), GSH peroxidase is separated from hemoglobin and catalase by chromatography on Sephadex G 150. The conditions given under methods proved to be adequate for fractionating $2 \mathrm{~m} l$ of an hemolysate. However, it should be emphasized that the determination of GSH peroxidase activity must be performed in the presence of azide ( $1 \mathrm{mM}$ ) to inhibit trace amounts of catalase which might nevertheless be present in the eluate of the columns. The procedure yields a recovery of $100 \%$ with a standard deviation of about $4 \%$ (6 experiments). The applicability of the method has not been tested with tissues other than erythrocytes.

\section{Definition of unit of activity}

As confirmed by several authors, the enzymatic oxidation of $\mathrm{GSH}$ by $\mathrm{H}_{2} \mathrm{O}_{2}$ is a first order reaction with regard to $\mathrm{GSH}$ and a zero order reaction with regard to $\mathrm{H}_{2} \mathrm{O}_{2}$ at concentrations above $10 \mu \mathrm{M}(2,3,11,12,20$, $21,22,26,28)$. These characteristics, especially the fact that no saturation by GSH is achieved, must be considered when defining the units of activity. The adequate consequence would be to present enzyme units as first order velocity constants $(2,12)$ or as $\Delta \mathrm{lg} \mathrm{c} / \mathrm{min}$ $(3,11)$. This is also true if the activity is measured by the method of Paglia and Valentine (13): Although a pseudo zero order reaction type is obtained by regenerating GSH, the reaction rate is nevertheless dependent on the initial concentration of GSH. Thus, the following definitions are possible:

$\mathrm{U}_{\mathrm{i}}=\Delta \ln \mathrm{CGSH}_{\mathrm{GS}} / \mathrm{min}=\mathrm{k}$

$\mathrm{U}_{1}=0.5 \Delta \mathrm{c}_{\mathrm{NADPH}} / \mathrm{c}_{0} \mathrm{GSH} \min$

$\mathrm{U}_{2}=\Delta \mathrm{lg} \mathrm{c}_{\mathrm{GSH}} / \mathrm{min}=0.434 \Delta \mathrm{ln} \mathrm{c}_{\mathrm{GSH}} / \mathrm{min}=0.434 \mathrm{k}$

$\mathrm{U}_{2}=0.217 \Delta \mathrm{c}_{\mathrm{NADPE}} / \mathrm{c}_{0} \mathrm{GSH} \mathrm{min}$

(3a) for instance is used by Gross and coworkers (2) and Cohen and Hochstein (12). An expression which differs from (4a) by a multiplication factor was applied by Mirts (11), while we prefer the expression (4a) for convenience. The expressions $(3 b)$ and $(4 b)$ are equivalent to (3a) and (4a), respectively, but may only be used if the method of PAGLita and VALENTINE (13) or the above modification (procedure II) is employed, i. e. if the turnover of substrate is a linear function of time.

\section{Conclusions}

1. Purification of GSH peroxidase prior to quantitative determination must occur in order to obtain results which are attributable to the enzyme itself. For a screening method, however, the pretreatment of Paglia and Valentine may be sufficient.

2. The influence of $\mathrm{pH}$, the nature and ionic strenght of the buffer, especially the kind and molarity of the anions must be considered.

3. Direct determination of substrate or product by chemical or enzymatic methods appears to be superior to the coupled enzymatic test, at least at unusual concentrations of the substrates.

4. The concentration of $\mathrm{H}_{2} \mathrm{O}_{2}$ should be high enough (depending on enzyme activity and cosubstrate concentration) to guarantee pseudo zero order kinetics with respect to this substrate.

5. The activity of GSH peroxidase should be presented in expressions which consider the kinetics of the reaction.

\section{Acknowledgments}

The skillful technical assistence of Mrs. I. MüLLER is gratefully acknowledged. The authors further wish to thank Prof. Dr. F. SCHNEIDER for his interest in the subject and the valuable discussions during the course of these investigations. This work was supported by a grant of the Deutsche Forschungsgemeinschaft. 


\section{References}

1. Mills, G. C. and H. P. Randall, J. biol. Chemistry 232, 589 (1958). - 2. Gross, R. T., R. Bracci, N. Rudolph, E. SchrogDER and J. A. KOCHEN, Blood 29, 481 (1967). - 3. SCHNEIDER, F. and L. Frohé, Hoppe-Seyler's Z. physiol. Chem. 348, 540 (1967). - 4. Mrlls, G. C., Arch. Biochim. Biophysics 86, 1 (1960). 5. Pirie, A., Biochem. J. 96, 244 (1965). - 6. Litrie, C. and P. J. O'Brien, Biochem. Biophys. Res. Commun. 31, 145 (1968). 7. Neubert, D., A. B. Wojtczak and A. L. Lehininger, Proc. Natl. Acad. Sci. U.S. 48, 1651 (1962). - 8. Christophersen, B. O., Biochim. biophysica Acta, Amsterdam 164, 35 (1968). 9. Chiristophersen, B. O., Biochim. biophysica Acta, Amsterdam 176, 463 (1969). - 10. Mills, G. C., J. biol. Chemistry 229, 189 (1957). - 11. Mrlus, G. C., J. biol. Chemistry 234, 502 (1959). 12. Cohen, G. and P. Hochistein, Biochemistry USA 2, 1420 (1963). - 13. Pagila, D. E. and W. N. Valentrine, J. Laborat. Clin. Med., S. Louis 70, 158 (1967). - 14. FLOHÉ, L., Biochem. Diplomarbeit, Tübingen (1966). - 15. Drabkin, D. L., Arch. Biochim. Biophysics 21, 224 (1949). - 16. SAunders, B. C.,
A. G. Holares-Siedle and B. P. Stark, Peroxidase, Butterworths, London (1964). - 17. Lowry, O. H., N. J. Rosebrough, A. L. FARR and R. J. RANDALt, J. biol. Chemistry 193, 265 (1951). 18. Thauer, R. K., A. Meiforti and J. Uehleke, Arch. exper. Path. Pharmak. 252, 291 (1965). - 19. HoRN, H. D. in: H. U. Bergmeyer, Methoden der envymatisclien Anal'se, Verlag Chemie GmbH, Weinheim (1962). - 20. Hochistern, P. and H. UtLey, Mol. Pharmacol. 4, 574 (1968). - 21. FlohÉ, L. and I. Brand, Bioch im. biophysica Acta, Amsterdam 191, 541 (1969). - 22. FLOHÉ, I., Hoppe-Seyler's Z. physiol. Chem. 350, 1181 (1969). - 23. Scorr, E. M., J. W. Duncan and V. Ekstrand, J. biol. Chemistry 238, 3928 (1963). - 24. Pinto, R. E. and W. Bartley, Biochem. J. 112, 109 (1969). - 25. Fuoнŕ, L., Hoppe-Seyler's Z. physiol. Chem. 350, 856 (1969). - 26. Flohí, L., W. Schleger and E. Schaich, this journal 8, $149(1970)$. - 27. Little, C. and P. J. O'Brien, Biochem. J. 102, 10 P (1967). - 28. Holmberg, N. J., Exptl. Eye Res. 7, 570 (1968).
Dr. L. Flohé 74 Tübingen Hoppe-Seyler-Str. 1 